\title{
Effects of Alkaline Additives on the Thermal Behavior and Properties of Cameroonian Poorly Fluxing Clay Ceramics
}

\author{
Antoine Elimbi ${ }^{*}$, Joseph M. Dika², Chantale N. Djangang1 \\ ${ }^{1}$ Department of Inorganic Chemistry, Faculty of Science, University of Yaoundé I, Yaoundé, \\ Cameroun \\ ${ }^{2}$ Department of Chemistry, Faculty of Science, University of Douala, Douala, Cameroon \\ Email: aelimbi2002@yahoo.fr
}

Received 8 April 2014; revised 10 May 2014; accepted 13 June 2014

Copyright @ 2014 by authors and Scientific Research Publishing Inc.

This work is licensed under the Creative Commons Attribution International License (CC BY). http://creativecommons.org/licenses/by/4.0/

(c) (7) Open Access

\begin{abstract}
Ball clay and alkaline feldspars (syenite and nepheline syenite) were mixed with red kaolinite clay (rich in iron oxides but poor in fluxing oxides) and fired $\left(1000^{\circ} \mathrm{C}-1200^{\circ} \mathrm{C}\right)$ in order to improve certain characteristics of the obtained ceramics. The thermal behavior of the mixtures was monitored via Young modulus whereas linear shrinkage, water absorption, bulk density, flexural strength, microstructure and crystalline phases of fired products were examined. In the case of red clay-ball clay mixtures, the amount of mullite or cristobalite increased with heating temperature and the amount of additive, whereas the temperature at which there is an important sintering decreased with the increase of additive. In the ceramics produced from the mixtures of red clay-alkaline additive, contrary to mullite, the amount of cristobalite decreased with both the amount of additive and heating temperature. Also in the data of Young modulus, there was a decrease of temperature assigned to the beginning of densification. Additionally, incorporating at least $15 \%$ of alkaline additive to red clay and heating between $1050^{\circ} \mathrm{C}$ and $1200^{\circ} \mathrm{C}$ leads to ceramics with low water absorption $(0.70 \%$ to $0.25 \%)$. However when using the same amount of additive and heating the mixtures at the same temperature, ceramics produced from nepheline syenite were denser than those obtained from syenite. Addition of ball clay or alkaline feldspars to kaolinite clay containing great amount of iron oxides and low fluxing oxides allows getting compact ceramics at reduced temperature.
\end{abstract}

\section{Keywords}

Clay, Syenite, Nepheline Syenite, Ceramics, Reduced Temperature

\footnotetext{
${ }^{*}$ Corresponding author.
} 


\section{Introduction}

In nature, clayey material is commonly composed of one or more clay minerals associated to non-clay minerals such as quartz, goethite, calcite, feldspars, organic matter, etc. On firing, clayey material undergoes many physico-chemical transformations which lead to common ceramics such as bricks, floor and roofing tiles, etc. Depending on both the chemical and mineralogical composition of clayey material, temperatures necessary to mature ceramic products whose characteristics must correspond to recommended norms can be more or less high [1]. For clayey material rich both in alkaline and iron oxides, the microstructure is highly modified at moderate temperature and ceramics with good characteristics can be obtained because vitrification generally appears between $900^{\circ} \mathrm{C}$ and $1100^{\circ} \mathrm{C}$ [2] [3]. On the contrary, the maturing temperature of ceramics of clayey material rich in iron oxides and poor in alkaline oxides is high [4]-[6]. In order to remedy the latter, an alternative can consist of making mixtures of both clayey material and additives rich in alkaline oxides [7]-[9]. Though the ceramic formation often involves solid-solid diffusion, the role of fluxes is to promote the formation of an amorphous phase that will act as a phase formation promoter, a binder and a glass. Its residual liquid fraction is converted into a vitreous compound when cooled. Among fluxes commonly used, sodium and potassium feldspars are of better choice [10]. Syenite is a flux that is generally used in the composition of many ceramic products such as sanitary, table and electric porcelains [11]. Nepheline syenite whose content in $\mathrm{K}_{2} \mathrm{O}+\mathrm{Na}_{2} \mathrm{O}$ is generally higher than $14 \%$ and does not contain quartz has a melting point lower than that of potassium feldspar. These two latter fluxes are abundantly present on the Cameroonian territory [12] [13].

Cameroon possesses an important potential of raw materials that can be used for the production of ceramics [14]. However, their value is still homemade and the products manufactured are essentially bricks, roofing tiles and pottery products [14]. The main company that produced ceramics in Cameroon (Céramiques Industrielles du Cameroun), mostly producing floor and wall tiles and certain type of plates existed only from 1976 to 1983. Several factors were responsible for this and among them a poor mastery of the clay-based raw material (Bomkoul clays). Today, business ventures contracted between Cameroonian, Chinese and Italian business men are being revised so as to solidify this activity.

In many localities of Sub-Saharan Africa and elsewhere around the world, chemical analysis of kaolinite clays indicates presence of high percentage of iron oxides and low percentage of alkaline oxides [6] [15]-[17]. During the making of common ceramics such as bricks, floor or roofing tiles from such clays, certain researchers elaborate mixtures whose compositions contain low waste materials as additive [18]-[20].

The large clay deposit of Bomkoul is composed of two types of materials: red clay referenced as $\mathrm{B}_{1}$ and grey clay labeled as $B_{2} . B_{1}$ is rich in iron oxides but poor in alkaline oxides [21]. Up to 1982's, a local industrial company in Cameroon used the Bomkoul clays for manufacturing ceramics. An anonymous document reports that the $\mathrm{B}_{1}$ clay was particularly used to produce floor and wall tiles. However, in spite of experimented mixtures that were done between $\mathrm{B}_{1}$ and additives to make satisfactory products, the quality of resulting ceramics was poor. A former study carried out on the properties of fired products of these clayey materials showed that ceramics from $B_{1}$ are red but maturity temperature of its products is relatively high compared to those from $B_{2}$ [3]. The aim of the present work is to set up conditions to lower maturity temperature of kaolinite clays which contain high amount of iron oxides and low amount of alkaline oxides. For this purpose, mixtures were made up using $\mathrm{B}_{1}$ clayey material and additives, respectively ball clay ( $\mathrm{B}_{2}$ from the Bomkoul clay deposit), syenite and nepheline syenite. The thermal behavior of different mixtures was followed up via Young modulus versus temperature $\left(20^{\circ} \mathrm{C}\right.$ to $\left.1300^{\circ} \mathrm{C}\right)$ while characteristics such as linear shrinkage, water absorption, bulk density, flexural strength, microstructure and crystalline phases of fired products were determined as a function of percentage of additive and temperature $\left(1000^{\circ} \mathrm{C}-1200^{\circ} \mathrm{C}\right)$.

\section{Materials and Geological Settings}

The Bomkoul clay deposit is located in the east of the sub-basin of Douala between longitudes $4^{\circ} 05^{\prime}$ and $4^{\circ} 06^{\prime}$ North and latitudes $9^{\circ} 47^{\prime}$ and $9^{\circ} 50^{\prime}$ East [21]. It is part of the Matanda formation since the Eocene-Paleocene era and is made up predominantly of deltaic deposits (Figure 1). This clay deposit extends over an area of $12 \mathrm{~km}^{2}$ and consists in two clay layers: one of which is red (1.5 to $3 \mathrm{~m}$ average depth) and the other gray ( 3 to $12 \mathrm{~m}$ average depth) [22]. The red clay referenced as $B_{1}$ is plastic and its maturity temperature intended to terra cotta is around $1200^{\circ} \mathrm{C}$ [3]. The gray clay referenced as $\mathrm{B}_{2}$ is a ball clay and the maturity temperature of its fired products is lower than $1150^{\circ} \mathrm{C}$ [3]. Table 1 and Figure 2 give the chemical and the mineralogical compositions of 


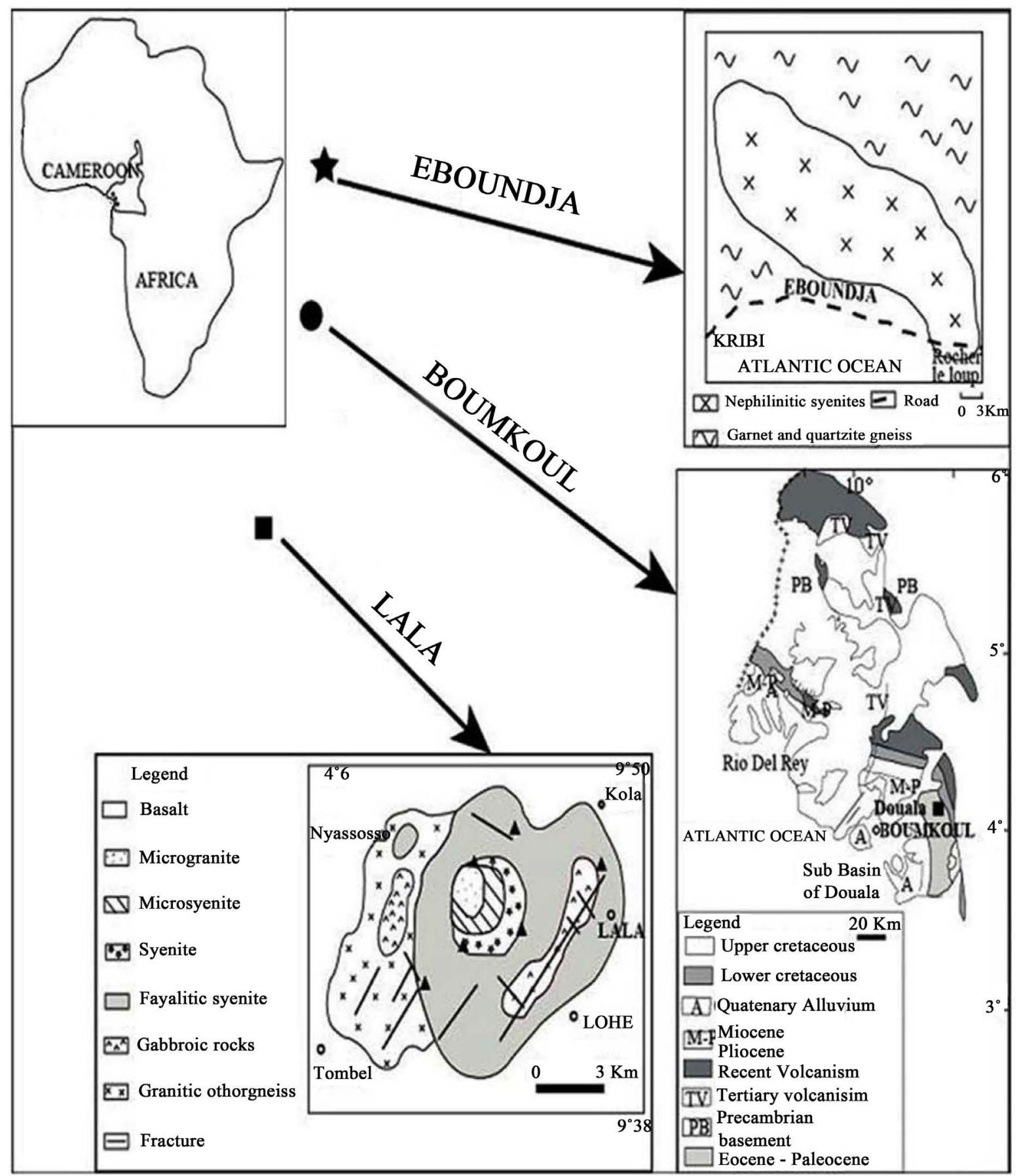

Figure 1. Geological sketch of the areas and locations where the samples were collected [22]-[24].

Table 1. Chemical composition of the clays and the fluxes expressed as wt\% oxides. (N.D. = Not Detected).

\begin{tabular}{cccccccccccc}
\hline Material & $\mathrm{SiO}_{2}$ & $\mathrm{Al}_{2} \mathrm{O}_{3}$ & $\mathrm{Fe}_{2} \mathrm{O}_{3}$ & $\mathrm{TiO}_{2}$ & $\mathrm{MnO}$ & $\mathrm{CaO}$ & $\mathrm{MgO}$ & $\mathrm{K}_{2} \mathrm{O}$ & $\mathrm{Na}_{2} \mathrm{O}$ & L.O.I. & Total \\
\hline $\mathrm{B}_{1}$ & 48.01 & 27.41 & 7.34 & 2.34 & 0.12 & 0.06 & 0.31 & 0.41 & 0.02 & 13.83 & 99.85 \\
$\mathrm{~B}_{2}$ & 49.45 & 25.96 & 5.13 & 2.05 & 0.06 & 0.18 & 0.94 & 1.05 & 0.09 & 14.44 & 99.35 \\
$\mathrm{SL}$ & 64.9 & 15.8 & 5.17 & 0.30 & $\mathrm{ND}$ & 1.61 & 0.13 & 5.89 & 5.40 & 0.71 & 99.9 \\
$\mathrm{SK}$ & 55.1 & 22.1 & 2.75 & 0.15 & $\mathrm{ND}$ & 2.54 & 0.13 & 8.37 & 7.32 & 1.45 & 99.9 \\
\hline
\end{tabular}



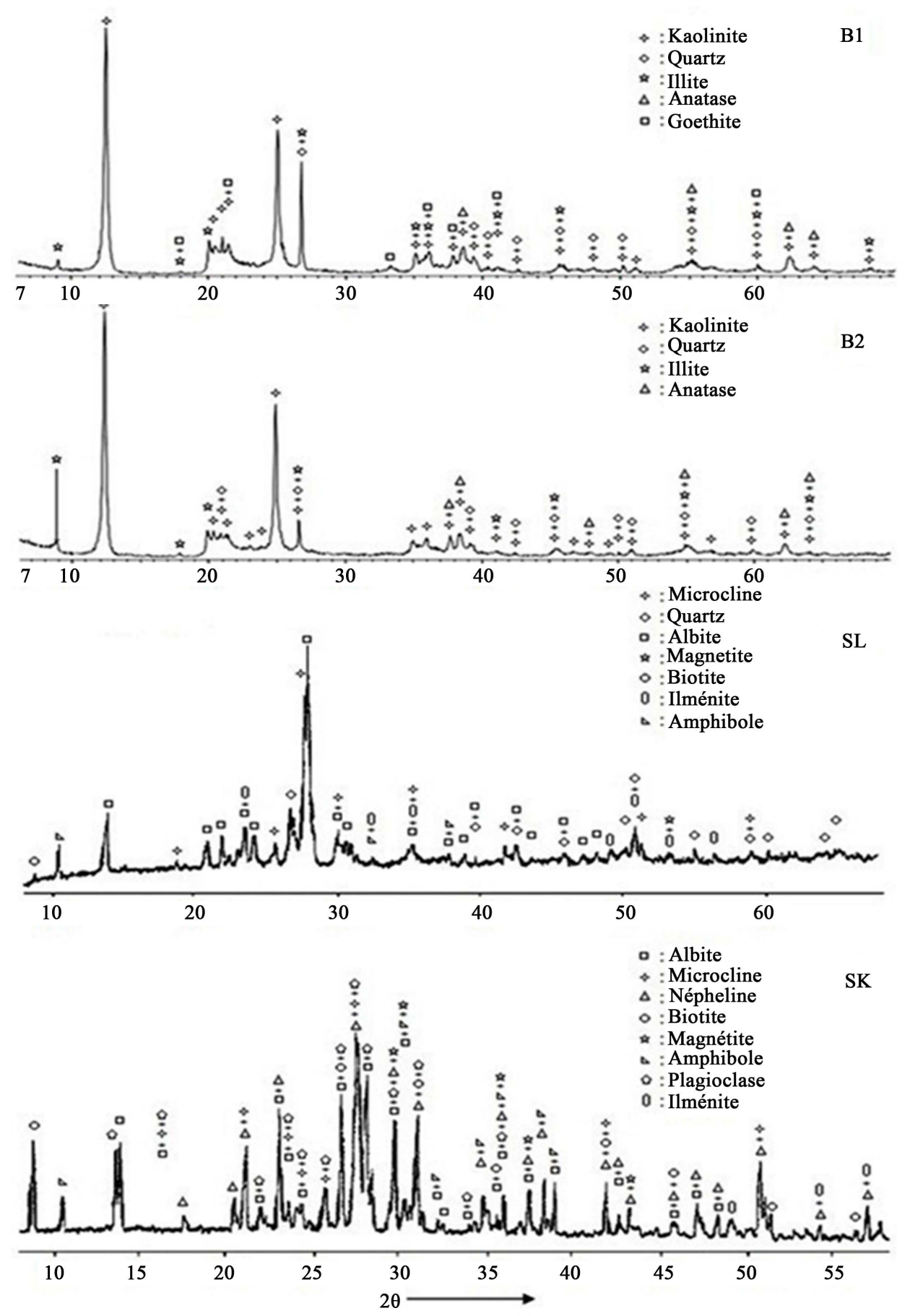

Figure 2. XRD patters of the clays $\left(\mathrm{B}_{1}\right.$ and $\left.\mathrm{B}_{2}\right)$ and the fluxes (SL and SK).

these clayey materials. The Eboundja syenite massive occurs in the form of lens (Figure 1) which extends over a distance of close to $40 \mathrm{~km}$. This massive is partially covered up and its visible part which contains nepheline syenite (denoted as SK) occupies an area of less than $20 \mathrm{~km}^{2}$ [23]. The Koupé massif includes the Lala village and is located between latitudes $4^{\circ} 43^{\prime}$ and $4^{\circ} 52^{\prime}$ North and longitudes $9^{\circ} 40^{\prime}$ and $9^{\circ} 47^{\prime}$ East. The massif has an elliptical shape with a maximum length of $11 \mathrm{~km}$ by a breadth of $8.5 \mathrm{~km}$ (Figure 1). This massif is made up of syenite rock, gabbroic rocks and basalt. The syenite rock denoted as SL covers a surface area close to $32 \mathrm{~km}^{2}$ [24]. Table 1 and Figure 2 show the chemical and the mineralogical compositions of SL and SK. 


\section{Experimental Methods}

Elaborated mixtures were of three types: red clay $B_{1}$-grey clay $B_{2}\left(B_{1}-B_{2}\right)$, red clay $B_{1}$-syenite $S L\left(B_{1}-S L\right)$ and red clay $B_{1}$-nepheline syenite SK $\left(B_{1}-S K\right)$. The weight compositions of $B_{1}-B_{2}, B_{1}-S L$ and $B_{1}-S K$ are given respectively in Table 2. Powders of the materials were sieved through sieves of $125 \mu \mathrm{m}$ (clays) and $80 \mu \mathrm{m}$ (fluxes), well mixed in a mixer ( $\mathrm{M} \& \mathrm{O}$, model N50-G) for $15 \mathrm{~min}$ in accordance with the percentages of Table 2 and moistened with distilled water (5\% - 7\% of weight of dried material). The humidified materials were well mixed again for $10 \mathrm{~min}$ and later uniaxially pressed in a mold (SPECAC model) at $15 \mathrm{MPa}$. Test samples were made in accordance with the following characteristics: cylindrical form (height $6 \mathrm{~mm}$; radius $10 \mathrm{~mm}$ ) to examine densification parameters (linear shrinkage, water absorption, bulk density) and microstructure; parallelepiped form $(80 \mathrm{~mm} \times 40 \mathrm{~mm} \times 7 \mathrm{~mm})$ to measure flexural strength and to determine crystalline phases. Samples used to follow up Young modulus as a function of temperature were parallelepiped $(15 \mathrm{~mm} \times 15 \mathrm{~mm} \times 150 \mathrm{~mm})$. Before thermal treatment, all the samples were first dried at ambient temperature in the laboratory $\left(20^{\circ} \mathrm{C}-26^{\circ} \mathrm{C}\right)$ and later in an oven at $105^{\circ} \mathrm{C}$, respectively for 48 and 24 hours. Firing of the samples consisted of heating them between $1000^{\circ} \mathrm{C}$ and $1200^{\circ} \mathrm{C}$ for two hours, by increments of $50^{\circ} \mathrm{C}$ with a firing speed of $5^{\circ} \mathrm{C} / \mathrm{min}$. After firing, the samples were allowed to cool in ambient temperature of the furnace (Nabertherm, Mod. LH 60/14). In order to ensure good handling, samples used to follow up Young modulus as a function of temperature were preheated at $900^{\circ} \mathrm{C}$ for two hours with a firing ramp of $5^{\circ} \mathrm{C} / \mathrm{min}$ in the electric temperature-programmed furnace. Young modulus as a function of temperature was examined using the ultrasonic technique known as "Long bare mode" [25]. Physical characteristics of the ceramics (linear shrinkage, water absorption, bulk density) were determined according to the NF-P 18-554 standard [26] whereas flexural strength was measured in accordance with the EN100 standard [27]. Microstructure of the ceramics was determined via Scanning Electron Microscope by using a Hitachi S-2500. Crystalline phases which appeared within ceramics were determined by X-ray powder diffraction using a Philips PW 1710 diffractometer equipped with an automatic slit window operating by reflexion of $\mathrm{k} \alpha_{1}$ radiation under the following conditions: $30 \mathrm{kV} / 50 \mathrm{~mA}, 400$ cps sensitivity, angular sweep range $6^{\circ}<2 \theta<$ $70^{\circ}$ Quantitative comparison of amount of quartz, mullite and cristobalite contained in the products as a function of temperature and percentage of additive was achieved. For each of the preceding crystalline phases, variations of relative intensity (expressed as percentage) of selected peak were followed up via diffractograms. The selected peaks were as follow: $2 \theta=20.84^{\circ}\left(\mathrm{d}_{\mathrm{hhl}}=4.26 \AA\right)$ for quartz; $2 \theta=16.46^{\circ}\left(\mathrm{d}_{\mathrm{hkl}}=5.38 \AA\right.$ ) for mullite; $2 \theta=$ $21.92^{\circ}\left(\mathrm{d}_{\mathrm{hkl}}=4.07 \AA\right)$ for cristobalite.

\section{Results and Discussion}

\subsection{Mineralogical Composition of the Ceramics}

The X-ray diffraction analyses were focused on the mixtures treated at $1000^{\circ} \mathrm{C}, 1100^{\circ} \mathrm{C}$ and $1200^{\circ} \mathrm{C}$ for: $\mathrm{G}_{10}$ and $\mathrm{G}_{50}\left(\mathrm{~B}_{1}-\mathrm{B}_{2}\right)$; $\mathrm{SL}_{5}, \mathrm{SL}_{15}$ and $\mathrm{SL}_{25}\left(\mathrm{~B}_{1}-\mathrm{SL}\right)$; $\mathrm{SK}_{5}, \mathrm{SK}_{15}$ and $\mathrm{SK}_{25}\left(\mathrm{~B}_{1}-\mathrm{SK}\right)$. Quantitative comparison of amount of quartz, mullite and cristobalite contained in the mixtures as a function of temperature and percentage of additive was achieved and the results are shown in Figure 6. An examination of the X-ray diffractograms (Figures 3-5) revealed:

For $\mathrm{B}_{1}-\mathrm{B}_{2}$ ceramics, crystalline phases are shown in Figure 3. The amount of quartz in the products does not vary appreciably (Figure 6(a)) and kaolinite is transformed into mullite and cristobalite. These neo-crystalline phases are present from $1100^{\circ} \mathrm{C}$ in $\mathrm{G}_{50}$ to $1200^{\circ} \mathrm{C}$ in $\mathrm{G}_{10}$ (Figure 6(b) and Figure 6(c)). Since the previous re-

Table 2. Weight composition of the mixtures of $\mathrm{B}_{1}-\mathrm{B}_{2}, \mathrm{~B}_{1}-\mathrm{SL}$ and $\mathrm{B}_{1}$-SK expressed as $\mathrm{wt} \%$.

\begin{tabular}{cccccc}
\hline Material & \multicolumn{5}{c}{ Mixture } \\
\hline $\mathrm{B}_{2}(\%)$ & 10 & $\mathrm{G}_{20}$ & $\mathrm{G}_{30}$ & $\mathrm{G}_{40}$ & $\mathrm{G}_{50}$ \\
$\mathrm{~B}_{1}(\%)$ & 90 & 80 & 30 & 40 & 50 \\
& $\mathrm{SL}_{5}$ or $\mathrm{SK}_{5}$ & $\mathrm{SL}_{10}$ or $\mathrm{SK}_{10}$ & $\mathrm{SL}_{15}$ or $\mathrm{SK}_{15}$ & $\mathrm{SL}_{20}$ or $\mathrm{SK}_{20}$ & $\mathrm{SL}_{25}$ or $\mathrm{SK}_{25}$ \\
$\mathrm{SL}$ or SK (\%) & 5 & 10 & 15 & 20 & 25 \\
$\mathrm{~B}_{1}(\%)$ & 95 & 90 & 85 & 80 & 75 \\
\hline
\end{tabular}




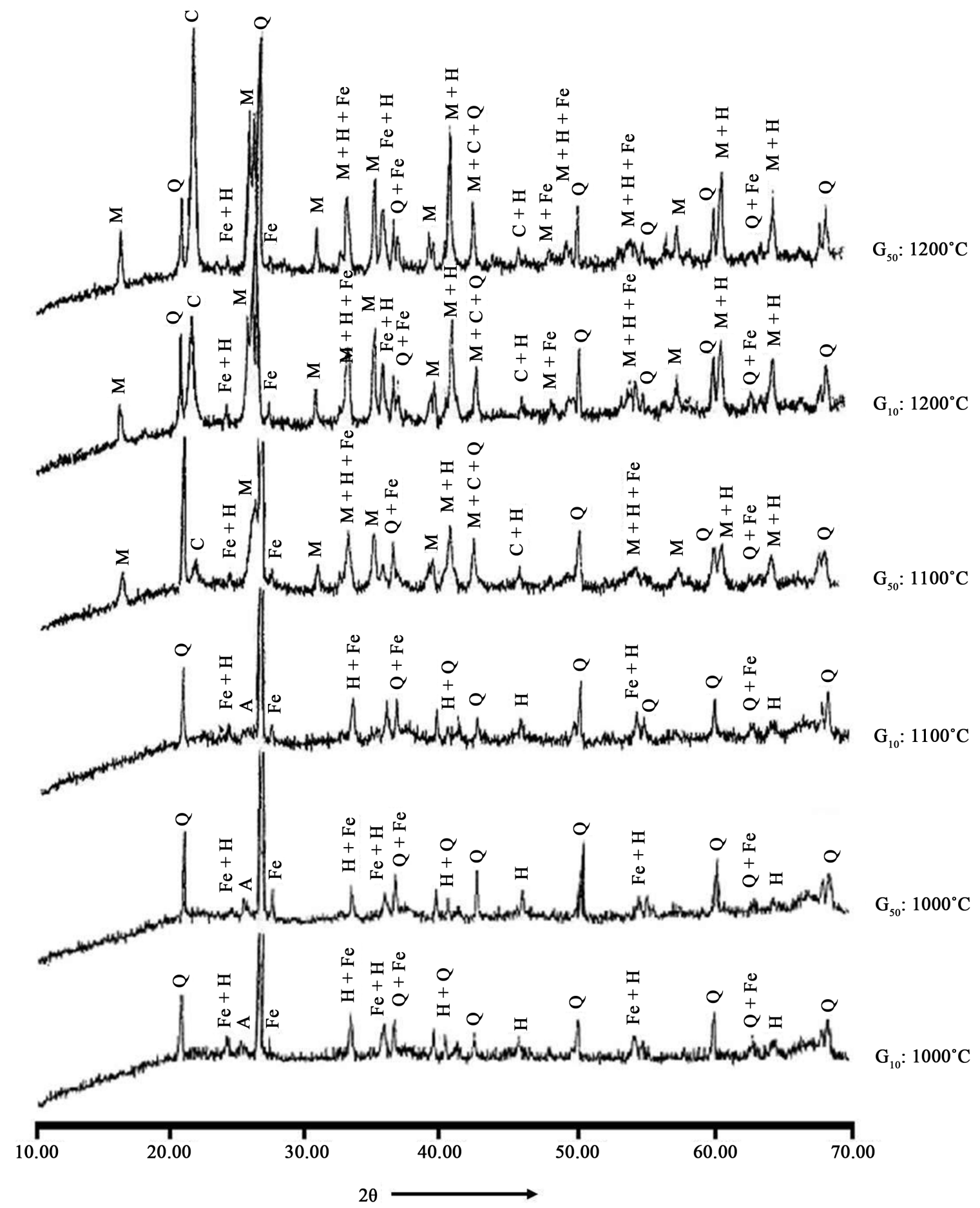

Figure 3. XRD patters of the fired mixtures of $\mathrm{B}_{1}-\mathrm{B}_{2}$ (Q: quartz; H: hematite; A: anatase; Fe: pseudorutile; M: mullite; $\mathrm{C}$ : cristobalite.

sults indicate that the ceramics of $\mathrm{B}_{1}$ fired up to $1100^{\circ} \mathrm{C}$ contain neither mullite nor cristobalite [3], it appears that mixing together $\mathrm{B}_{1}$ and $\mathrm{B}_{2}$ promotes the formation of these minerals in amounts which increase along with amount of additive $\left(\mathrm{B}_{2}\right)$ (Figure 6(b) and Figure 6(c)). Hematite originates from the thermal decomposition of goethite (Figure 2 and Figure 3) while pseudorutile could results from chemical reaction between anatase and hematite [28]. 


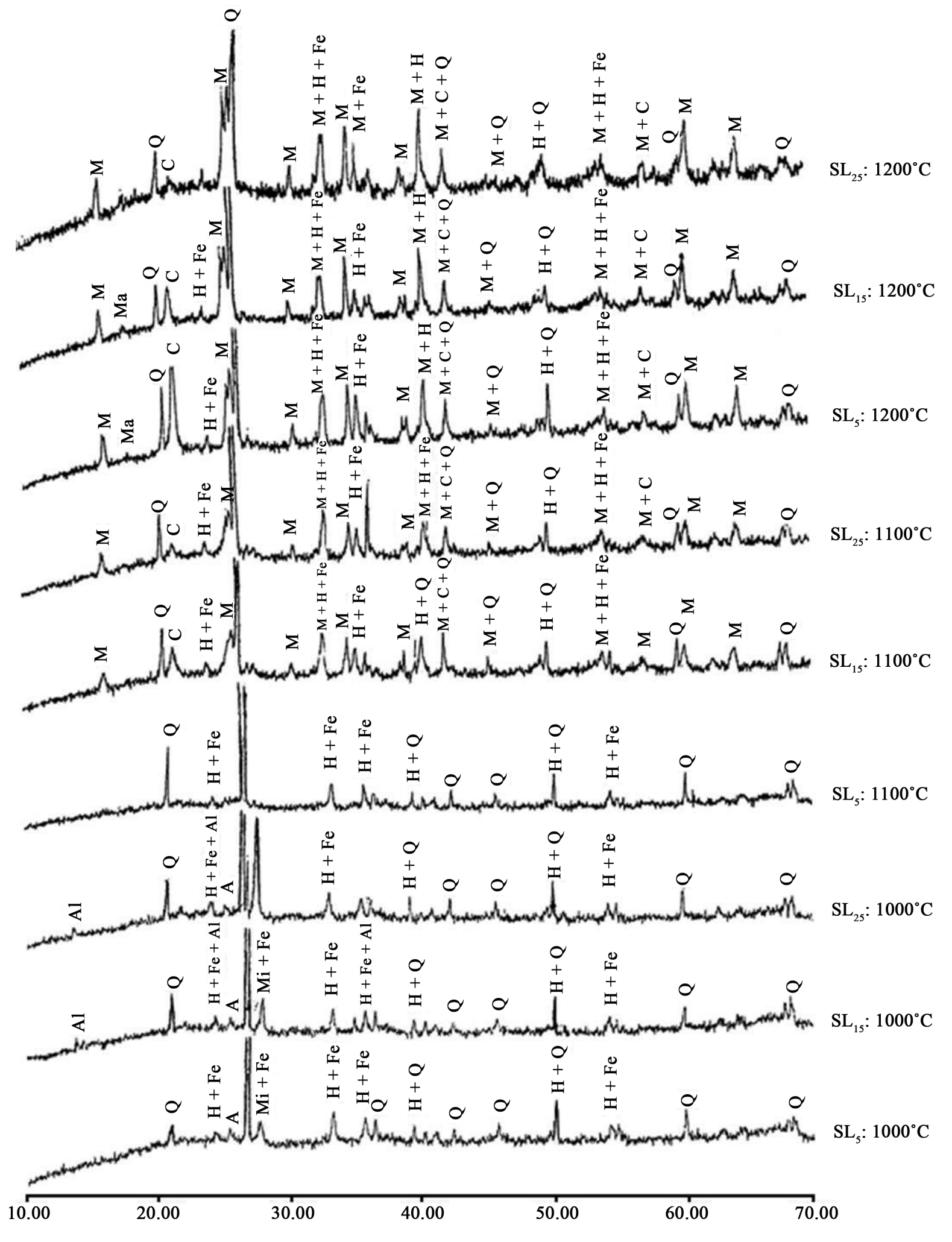

$2 \theta \longrightarrow$

Figure 4. XRD patterns of the fired mixtures of $\mathrm{B}_{1}-\mathrm{SL}$ (H: hematite; Q: quartz; Fe: pseudorutile; A: anatase; Mi: microcline; Al; albite; M: mullite; C: cristobalite). 


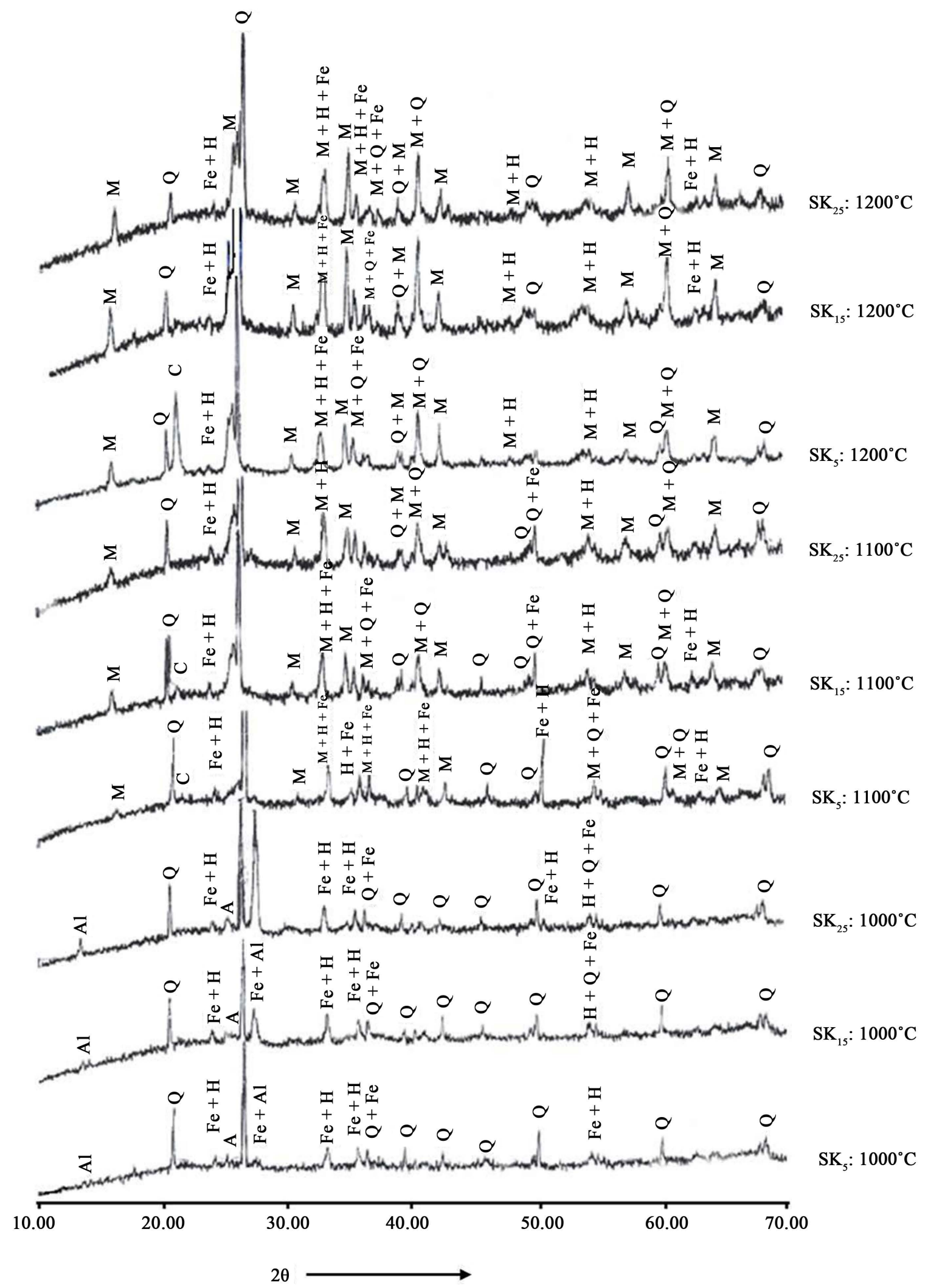

Figure 5. XRD patterns of the fired mixtures of $\mathrm{B}_{1}$-SK. (H: hematite; Q: quartz; Fe: pseudorutile; A: anatase; Al: albite; M: mullite; C: cristobalite). 

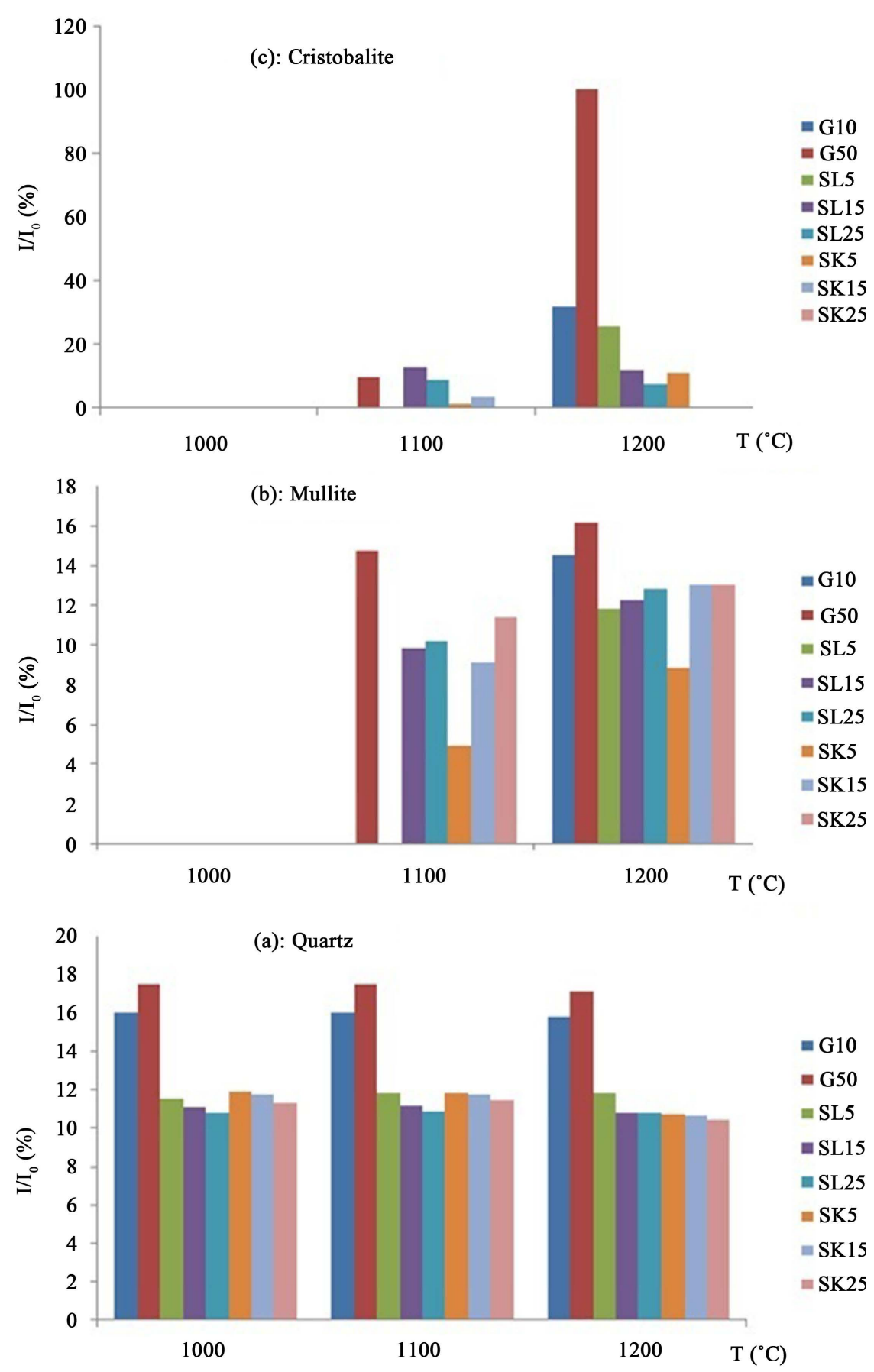

Figure 6. Quantitative comparison of the amount of quartz, mullite and cristobalite contained in the mixtures as a function of temperature and percentage of additive.

Figure 4 shows crystalline phases of the ceramics of $\mathrm{B}_{1}$-SL. From $1100^{\circ} \mathrm{C}$, albite and microcline are not more present which indicates their transformation into vitreous phase. This is clearly expressed at $1200^{\circ} \mathrm{C}$ (diffractograms of $\mathrm{SL}_{15}$ and $\mathrm{SL}_{25}$ ) by the appearance of a hump at $2 \theta$ between $17^{\circ}$ and $28^{\circ}$. There is a weak decrease of amount of quartz at $1200^{\circ} \mathrm{C}$ (Figure 6(a)) while mullite and cristobalite are observed from $1100^{\circ} \mathrm{C}_{\text {in }} \mathrm{SL}_{15}$ and $\mathrm{SL}_{25}$. However, increase of temperature leads to increase the amount of mullite and decrease the amount of cristobalite (Figure 6(b) and Figure 6(c)). At a same firing temperature, the amount of cristobalite is higher in $\mathrm{SL}_{15}$ than in $\mathrm{SL}_{25}$ (Figure 6(b)). It is well known that the presence of an abundant vitreous phase in aluminosilicate 
ceramics provokes the dissolution of cristobalite [29] which is in accordance with Figure 6(b). Hematite originates from the thermal decomposition of goethite while pseudorutile could result from the thermal reaction between anatase and hematite [28].

In the ceramics of $\mathrm{B}_{1}$-SK, the crystalline phases observed are shown in Figure 5. Albite is not more present from $1100^{\circ} \mathrm{C}$ which indicates its transformation into vitreous phase (hump at $2 \theta$ between $17^{\circ}$ and $28^{\circ}$ in the diffractograms of $\mathrm{SK}_{5}-\mathrm{SK}_{25}$ ). There is light decrease of the amount of quartz at $1200^{\circ} \mathrm{C}$ (Figure 6(a)) probably because it has reacted with vitreous phase [7]. Mullite is observed from $1100^{\circ} \mathrm{C}$ in the products of $\mathrm{SK}_{15-25}$ and its amount increases along with firing temperature (Figure 6(b)) while cristobalite is present at $1100^{\circ} \mathrm{C}$ in $\mathrm{SK}_{15}$ and at $1100^{\circ} \mathrm{C}$ and $1200^{\circ} \mathrm{C}$ in $\mathrm{SK}_{5}$ (Figure 5 and Figure $6(\mathrm{c})$ ). The absence of cristobalite in certain mixtures of $\mathrm{B}_{1^{-}}$ SK is expressed as its dissolution in an abundant vitreous phase [7]. Hematite originates from the thermal decomposition of goethite (Figure 2 and Figure 5) while pseudorutile may result from the reaction between anatase and hematite [28].

\subsection{Thermal Behavior of the Mixtures}

The variation of Young modulus (YM) versus temperature is sensitive to phase and microstructure changes within materials [30]. Figure 7 shows data of $\mathrm{YM}$ as a function of temperature of the mixtures preheated at $900^{\circ} \mathrm{C}$. For the samples $\mathrm{G}_{10}$ and $\mathrm{G}_{50}$ of $\mathrm{B}_{1}-\mathrm{B}_{2}$, three domains are observed (Figure $7(\mathrm{a})$ ). Above $334^{\circ} \mathrm{C}$, $\mathrm{YM}$ does
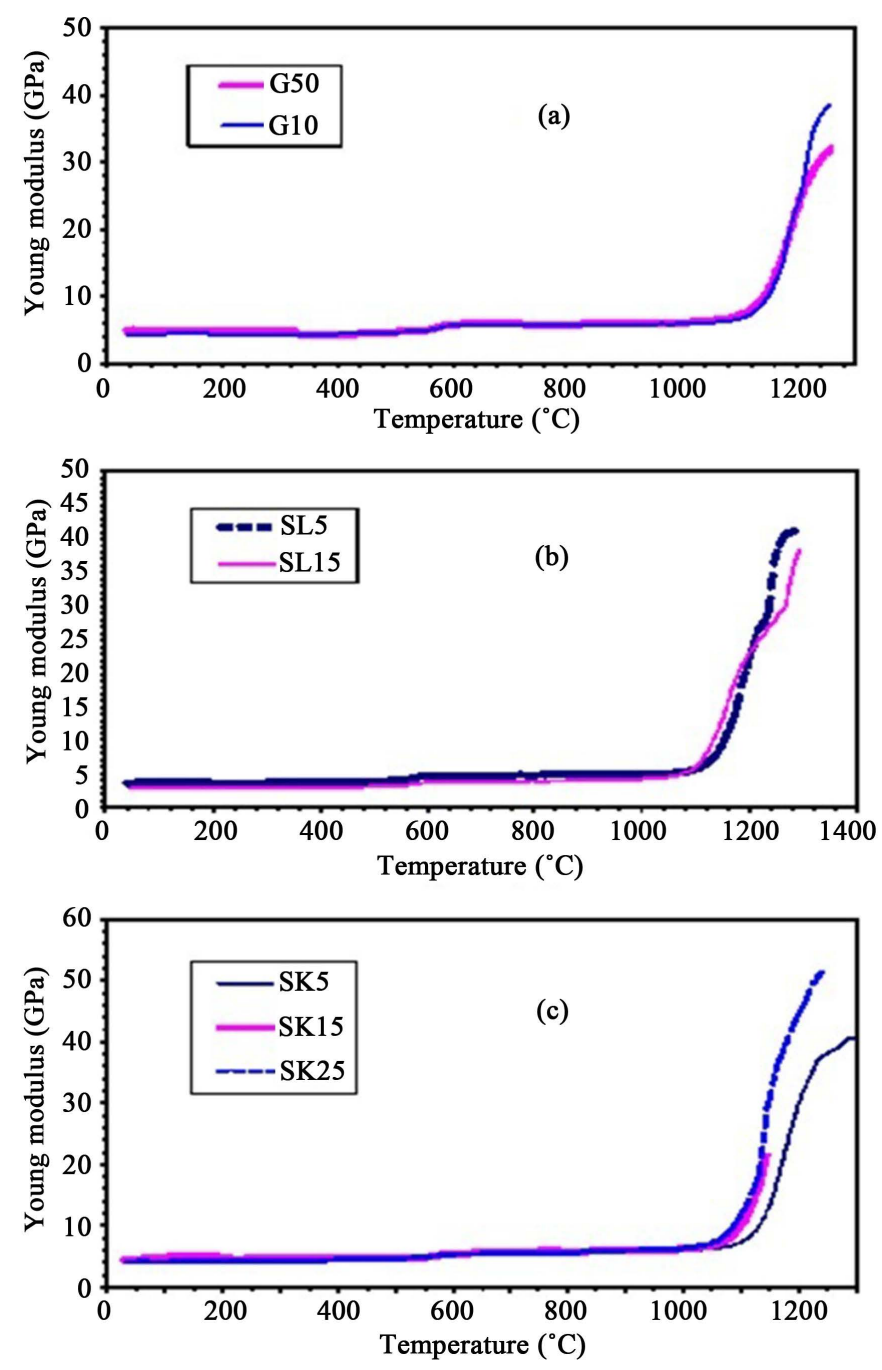

Figure 7. Data of Young modulus as a function of temperature for certain mixtures. ((a): $\mathrm{B}_{1}-\mathrm{B}_{2}$; (b): $\mathrm{B}_{1}-\mathrm{SL}$; (c): $\left.\mathrm{B}_{1}-\mathrm{SK}\right)$. 
not vary appreciably since the microstructure of the products is governed by phases such as quartz, metakaolinite and hematite previously present in the mixtures (pre-sintering temperature), except at $575^{\circ} \mathrm{C}$ where the polymorphism of quartz $\alpha$ into quartz $\beta$ leads to a weak increase of $\mathrm{YM}$. Between $1052^{\circ} \mathrm{C}$ and $1200^{\circ} \mathrm{C}$ there is a considerable increase of YM (+11.4 GPa) which is in accordance with the rearrangement of the network of metakaolinite followed by a significant sintering of the products [31]. In fact metakaolinite is transformed into spinel phase and amorphous silica [32]. Between $1184^{\circ} \mathrm{C}$ and $1235^{\circ} \mathrm{C} \mathrm{YM} \mathrm{of} \mathrm{G}_{10}$ increases uniformly while that of $\mathrm{G}_{50}$ deflects first at $1184^{\circ} \mathrm{C}$ and increases slightly later on. This difference is assigned to the mineralogical composition of their ceramics. In fact, Figure 3 indicates the presence of mullite and cristobalite as from $1100^{\circ} \mathrm{C}$ in $\mathrm{G}_{50}$ against $1200^{\circ} \mathrm{C}$ in $\mathrm{G}_{10}$. In the samples $\mathrm{SL}_{5}$ and $\mathrm{SL}_{15}$ of $\mathrm{B}_{1}-\mathrm{SL}$, three domains are also observed (Figure $7(\mathrm{~b})$ ). Up to $1066^{\circ} \mathrm{C}$, YM does not vary appreciably as result of intrinsic properties of the phases such as quartz and metakaolinite and hematite previously present in the mixtures. However there is slight increase of $\mathrm{YM}$ at $575^{\circ} \mathrm{C}$ as a result of the polymorphism of quartz $\alpha$ into quartz $\beta$. From $1066^{\circ} \mathrm{C}$ to $1170^{\circ} \mathrm{C}$, YM undergoes considerable increase which indicates both rearrangement of the network of metakaolinite and the beginning of sintering [29]. Elsewhere, albite and microcline melt from $1100^{\circ} \mathrm{C}$ (Figure 4) and bring about vitreous phase in the products. Thus YM increases since it is sensitive to the newly formed phases (spinel, amorphous silica and vitreous phase). However this increase begins at $1106^{\circ} \mathrm{C}$ (sample $\mathrm{SL}_{5}$ ) against $1066^{\circ} \mathrm{C}$ (sample $\mathrm{SL}_{15}$ ). This difference is assigned to the presence of more abundant amorphous phase in $\mathrm{SL}_{15}$ than in $\mathrm{SL}_{5}$. In fact before firing, the amount of flux (syenite SL) is greater in $\mathrm{SL}_{15}$ than in $\mathrm{SL}_{5}$. Consequently when SL melts down the amount of vitreous phase brought about is greater in the products of $\mathrm{SL}_{15}$ than in those of $\mathrm{SL}_{5}$. As result, the sintering temperature of $\mathrm{SL}_{15}$ is lower than that of $\mathrm{SL}_{5}$. Between $1177^{\circ} \mathrm{C}$ and $1237^{\circ} \mathrm{C}$, there is a deflection on the curve of $\mathrm{YM}$ of $\mathrm{SL}_{15}$ at $1177^{\circ} \mathrm{C}$ against $1237^{\circ} \mathrm{C}$ on that of $\mathrm{SL}_{5}$ (Figure $7(b)$ ). This difference is attributed to the mineralogical composition of their ceramics. In fact, the products of $\mathrm{SL}_{15}$ contain mullite and cristobalite from $1100^{\circ} \mathrm{C}$ against $1200^{\circ} \mathrm{C}$ in those of $\mathrm{SL}_{5}$ (Figure 4 and Figure 6(b) and Figure 6(c)). The curves of YM of the samples $\mathrm{SK}_{5}$, $\mathrm{SK}_{15}$ and $\mathrm{SK}_{25}$ show three domains each (Figure $7(\mathrm{c})$ ). $\mathrm{Up}$ to $1038^{\circ} \mathrm{C} \mathrm{C}, \mathrm{YM}$ is almost constant except at $575^{\circ} \mathrm{C}$ (polymorphism of quartz $\alpha$ into quartz $\beta$ ). Between $1038^{\circ} \mathrm{C}$ and $1129^{\circ} \mathrm{C}, \mathrm{YM}$ undergoes strong increase as result of concomitant effects of rearrangement of the network of metakaolinite and sintering of the products [29]. However the temperatures which correspond to the increase of $\mathrm{YM}$ are as follow: $1101^{\circ} \mathrm{C}\left(\mathrm{SK}_{5}\right), 1058^{\circ} \mathrm{C}\left(\mathrm{SK}_{15}\right)$ and $1038^{\circ} \mathrm{C}\left(\mathrm{SK}_{25}\right)$, (Figure $7(\mathrm{c})$ ). This behavior is the result of the presence of amorphous phase [29] within the ceramics and the more the amorphous phase is produced, the lower is the temperature at which the sintering begins. In fact the amount of flux in the mixtures increases from the sample $\mathrm{SK}_{5}$ to the sample $\mathrm{SK}_{25}$. Consequently, when the flux melts down, there is an increase of the amount of vitreous phase from the product of $\mathrm{SK}_{5}$ to that of $\mathrm{SK}_{25}$. From $1129^{\circ} \mathrm{C}$ to $1250^{\circ} \mathrm{C}$, YM increases and in each curve, there is a deflection whose temperature decreases along with the amount of additive: $1231^{\circ} \mathrm{C}\left(\mathrm{SK}_{5}\right), 1177^{\circ} \mathrm{C}\left(\mathrm{SK}_{15}\right)$ and $1166^{\circ} \mathrm{C}\left(\mathrm{SK}_{25}\right)$. On the other hand, mullite is observed from $1100^{\circ} \mathrm{C}$ in all the products (Figure 5) and its amount increases from the product of $\mathrm{SK}_{5}$ to that of $\mathrm{SK}_{25}$ (Figure 6(b)). Hence the presence of deflection in the YM curves depends on the amount of mullite: the greater the amount of mullite the lower the temperature of appearance of deflection.

\subsection{Microstructure of the Ceramics}

The microstructure of fired products is presented by the SEM micrographs of Figure 8. In general, the mixtures fired at $1000^{\circ} \mathrm{C}$ contain large blocks (fired clay aggregates) surrounded by granules (fired clay particles and nontransformed additive particles) of variable dimensions and the ceramics apparently manifest weak cohesion (Figure 8: micrographs a, b, e, f, i, j). In the samples of $B_{1}-B_{2}$ fired at $1000^{\circ} \mathrm{C}$, the higher the amount of additive $\left(B_{2}\right)$, the lower the particles surrounding fired clay aggregates (Figure 8: micrographs a and $b$ ). In fact $B_{2}$ is ball clay [3] and the mixtures that contain it in great amount are more plastic which leads to low individual particle products. On the contrary, the samples of $B_{1}-B_{2}$ fired at $1200^{\circ} \mathrm{C}$ are compact enough as result of good sintering but there are some cracks through some parts of the products (Figure 8: micrographs $\mathrm{c}$ and d) because of tensions due to the difference in thermal expansion coefficients between the amorphous phase (produced by minerals such as illite) and the crystalline phases (Figure 6(b): namely cristobalite and mullite). For the products of $\mathrm{B}_{1}$-SL and $\mathrm{B}_{1}$-SK fired at $1000^{\circ} \mathrm{C}$, mixtures with great amount of additive contain more granules (fired clay particles and non-transformed additive particles) than fired clay aggregates (Figure 8: micrographs $\mathrm{f}$ and $\mathrm{j}$ in comparison with micrographs e and i) because the fluxes (SL and SK) have not yet melt down. The mixtures fired at $1200^{\circ} \mathrm{C}$ are compact enough as a result of great amount of amorphous phase which fills pores and connects particles. However, the ceramics of $\mathrm{B}_{1}$-SL (Figure 8: micrographs $\mathrm{g}$ and $\mathrm{h}$ ) exhibit more cracks and pores than 

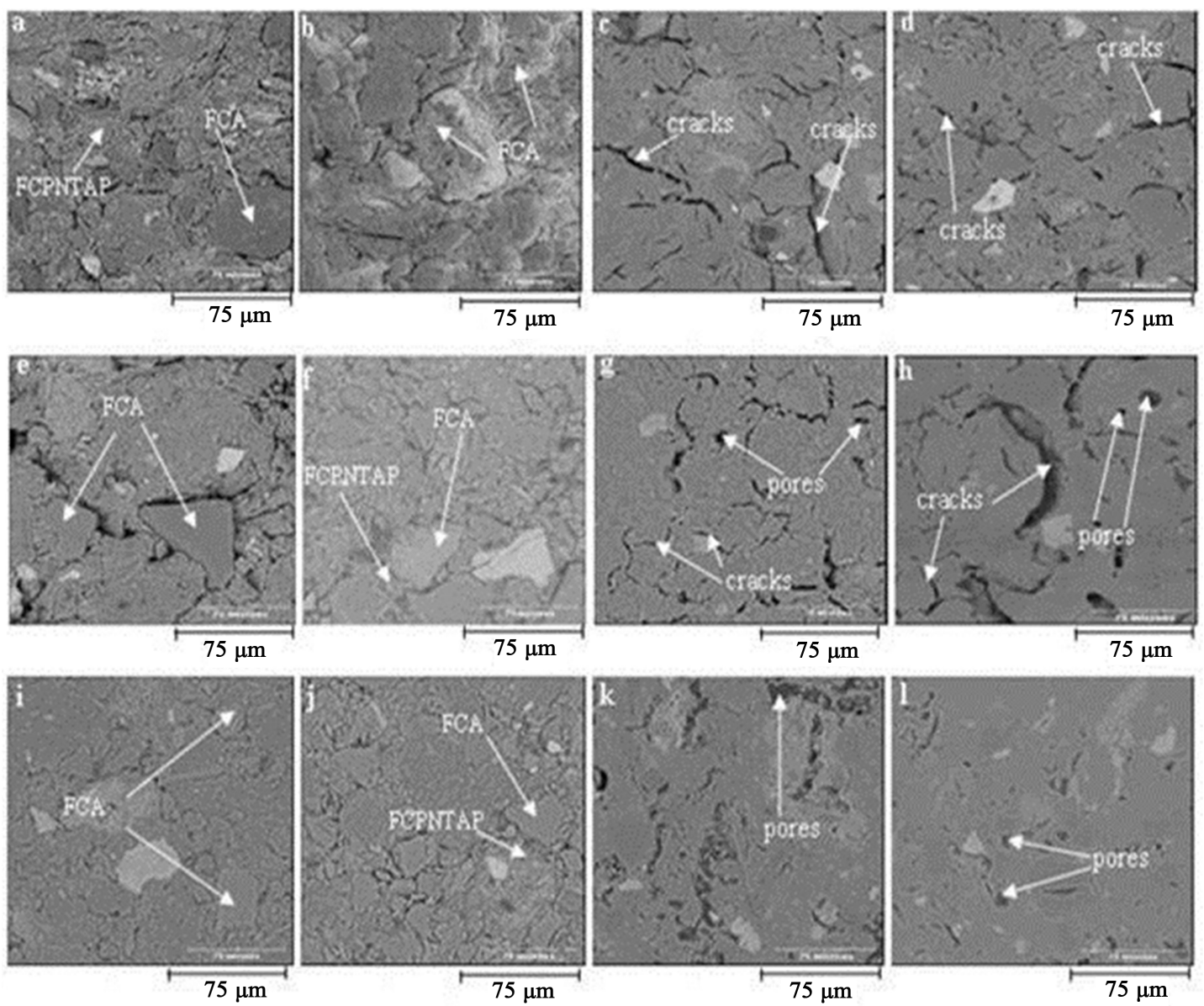

Figure 8. Micrographs of the fired mixtures of $B_{1}-B_{2}$; $B_{1}-S L$ and $B_{1}-S K .\left((a): G_{10}: 1000^{\circ} \mathrm{C}\right.$; (b): $G_{50}: 1000^{\circ} \mathrm{C}$; (c): $\mathrm{G}_{10}: 1200^{\circ} \mathrm{C}$; (d): $\mathrm{G}_{50}: 1200^{\circ} \mathrm{C}$; (e): $\mathrm{SL}_{5}: 1000^{\circ} \mathrm{C}$; (f): $\mathrm{SL}_{25}: 1000^{\circ} \mathrm{C}$; (g): SL $5: 1200^{\circ} \mathrm{C}$; (h): $\mathrm{SL}_{25}: 1200^{\circ} \mathrm{C}$; (i): $\mathrm{SK}_{5}$ : $1000^{\circ} \mathrm{C}$; (j): $\mathrm{SK}_{25}: 1000^{\circ} \mathrm{C}$; (k): $\mathrm{SK}_{5}: 1200^{\circ} \mathrm{C}$; (l): $\left.\mathrm{SK}_{25}: 1200^{\circ} \mathrm{C}\right)$.

those of $\mathrm{B}_{1}$-SK (Figure 8: micrographs $\mathrm{k}$ and $\mathrm{l}$ ) which presumably results from the fact that the amorphous phase produced by SK (nepheline syenite) is more wetting than the one produced by SL (syenite) [30]. This allows amorphous phase produced by SK to connect better the particles. On the contrary, the amorphous phase produced by SL is more viscous and generates cracks during the cooling. This results from the difference between the thermal expansion coefficients of the rigid amorphous phase and the crystalline particles (quartz, mullite and cristobalite).

\subsection{Physical and Mechanical Properties of the Ceramics}

Data of physical and mechanical characteristics of the ceramics as a function of the amount of additive and temperature are shown in Figures 9-11. In the ceramics of $B_{1}-B_{2}$, linear shrinkage increases along with temperature and amount of additive $\left(B_{2}\right)$, except for $G_{10}$ respectively at $1150^{\circ} \mathrm{C}$ and $1200^{\circ} \mathrm{C}$ and ${ }_{\text {for }} \mathrm{G}_{40}$ and $\mathrm{G}_{50}$ at $1200^{\circ} \mathrm{C}$ (Figure 9(a)). This increase indicates of the level of physico-chemical transformations that take place in the materials [31]. However at $1150^{\circ} \mathrm{C}$ and $1200^{\circ} \mathrm{C}$, the values of linear shrinkage of $\mathrm{G}_{10}$ are slightly lower than those of $G_{0}$ since the mineralogical composition of their mixtures differs notably ( $G_{0}$ contains no additive). By contrast, the mixtures of $\mathrm{G}_{10-30}$ have the same mineralogical composition and their linear shrinkage increase slightly along with additive $\left(\mathrm{B}_{2}\right)$ until the amount of cristobalite reaches a high level (Figure 6(c)). The presence of high amount of cristobalite in aluminosilicate ceramics generally generates the bloating of products [4] [25]. Thus the presence of great amount of cristobalite in the products of $\mathrm{G}_{40-50}$ explains the decrease of linear shrinkage at $1200^{\circ} \mathrm{C}$ (Figure 6(c) and Figure 9(a)). Increasing the temperature leads to decrease the water absorption and increase the bulk density (Figure 9(b) and Figure 9(c)). This is a result of sintering which is promoted 

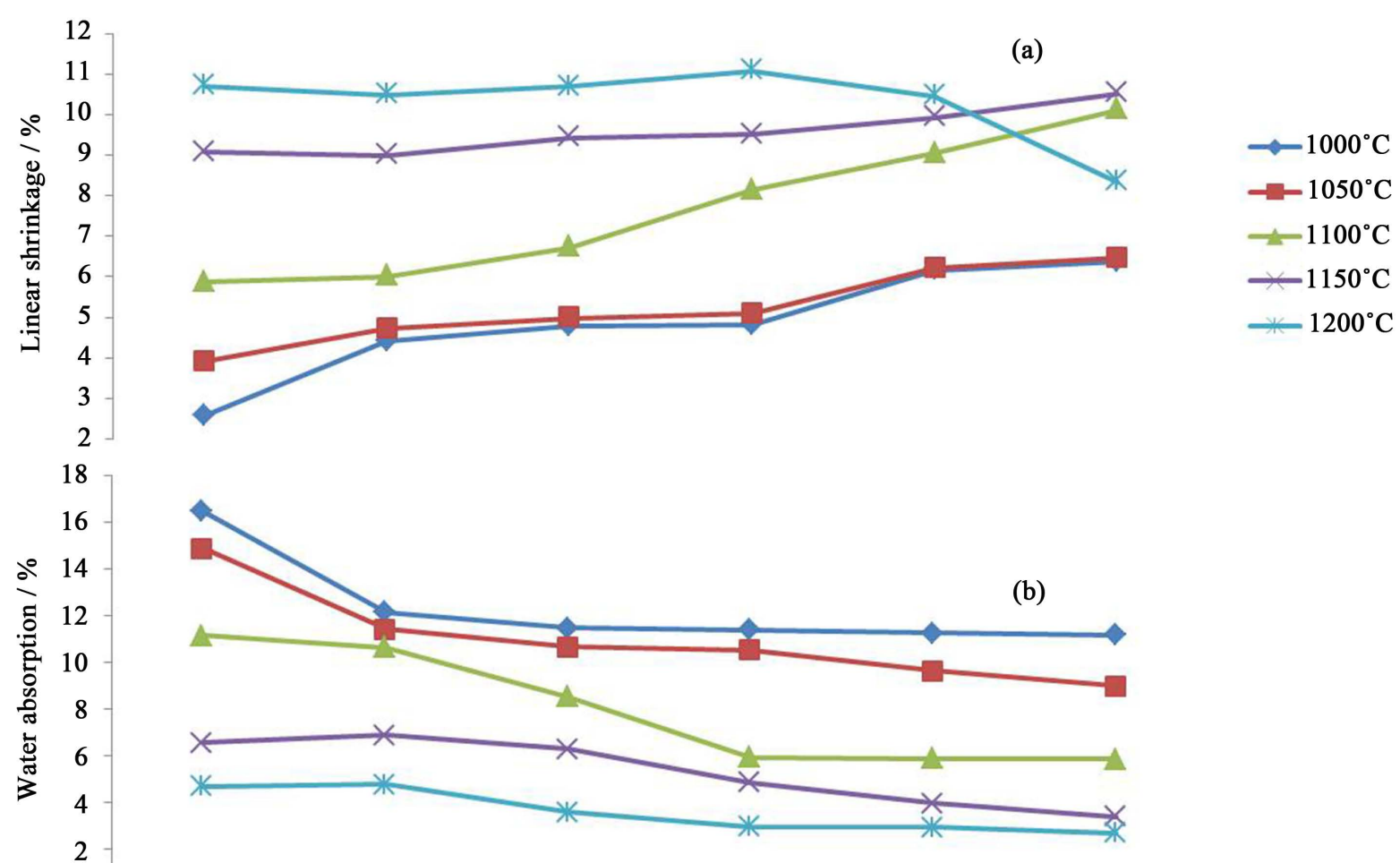

(c)
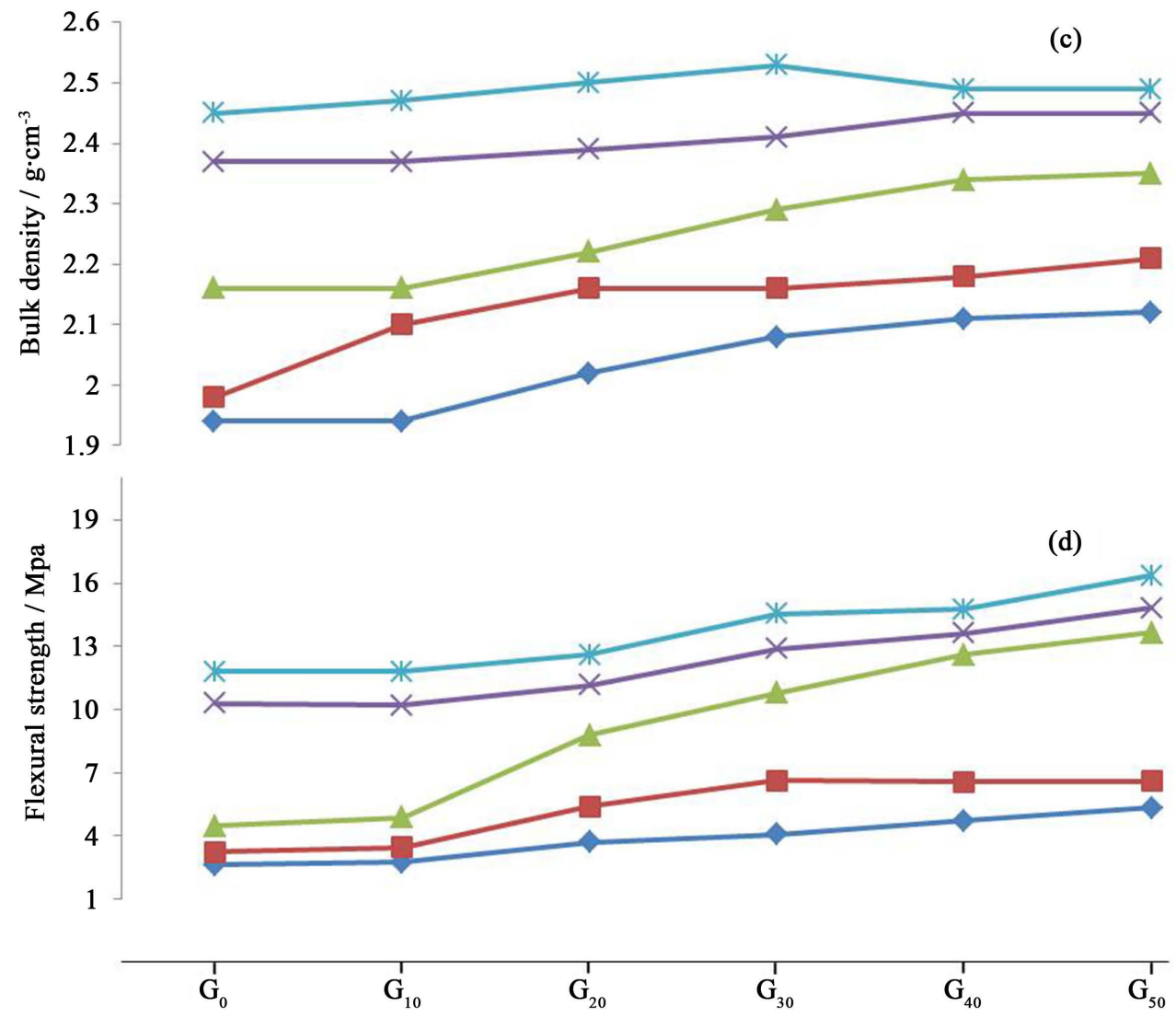

Figure 9. Physical and flexural strength of ceramics of the mixtures of $\mathrm{B}_{1}-\mathrm{B}_{2}$ as a function of amount of additive $\left(\mathrm{B}_{2}\right)$ and temperature. ((a): linear shrinkage; (b): water absorption; (c): bulk density; (e): flexural strength). 


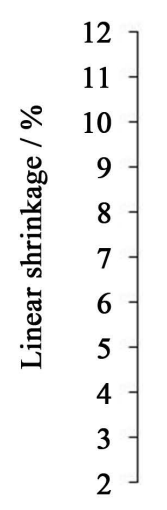

(a)

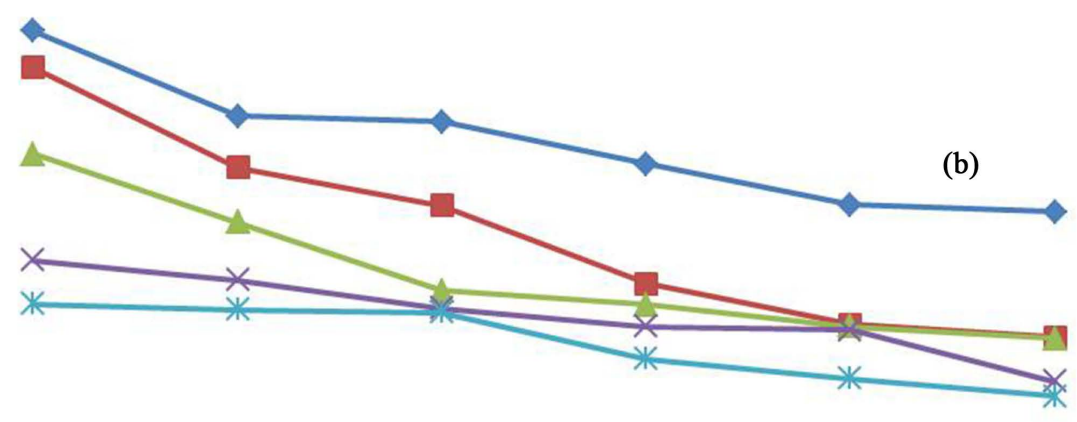

(c)
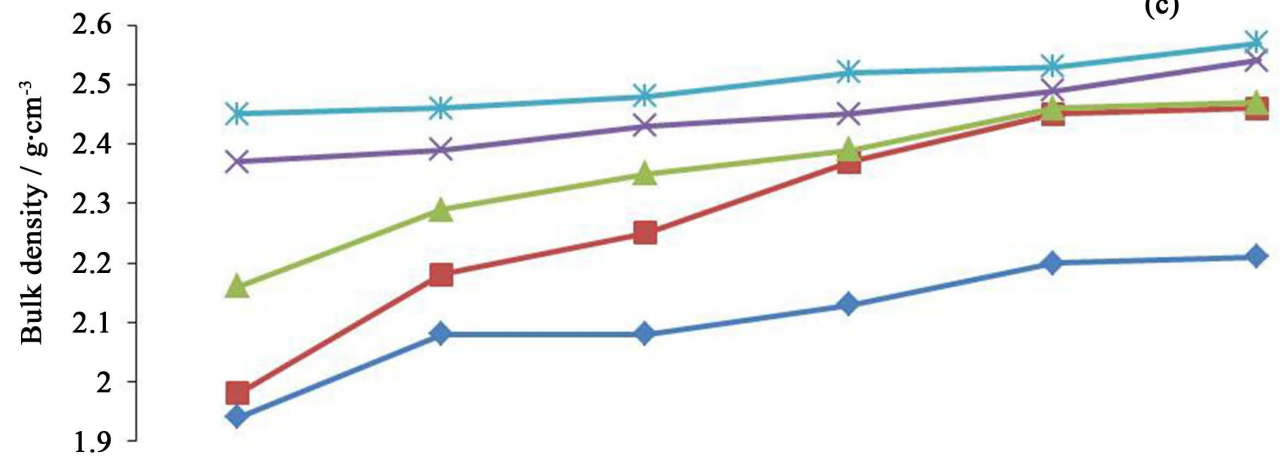

(d)
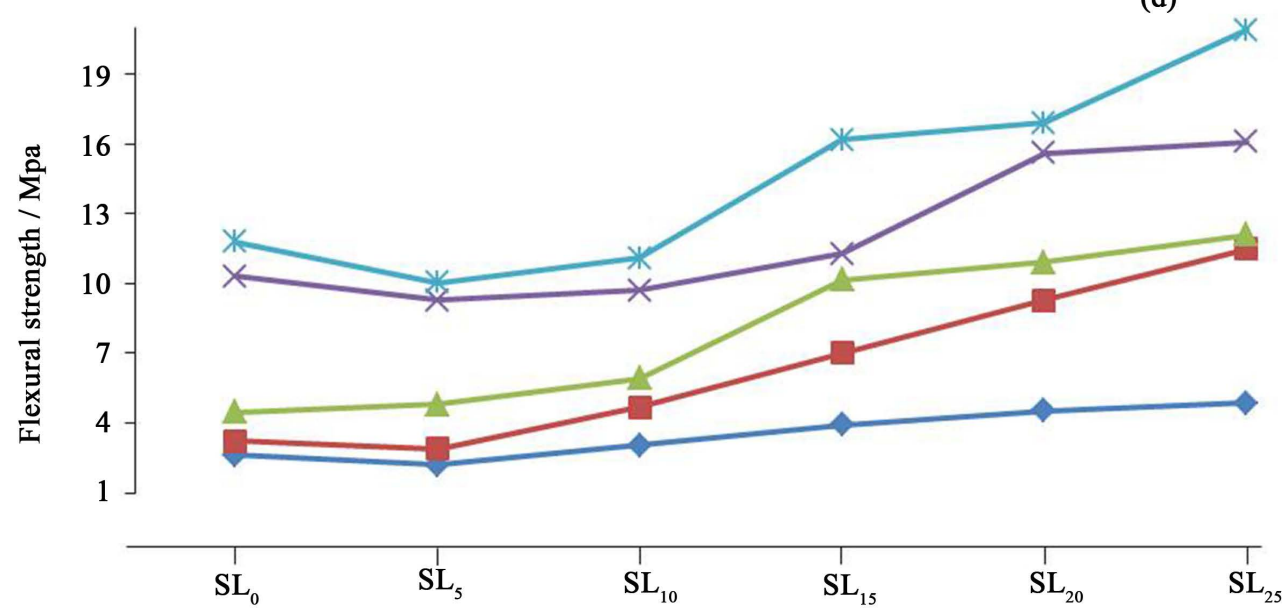

Figure 10. Physical and flexural strength of ceramics of the mixtures of $\mathrm{B}_{1}$-SL as a function of amount of additive (SL) and temperature. ((a): linear shrinkage; (b): water absorption; (c): bulk density; (d): flexural strength). 

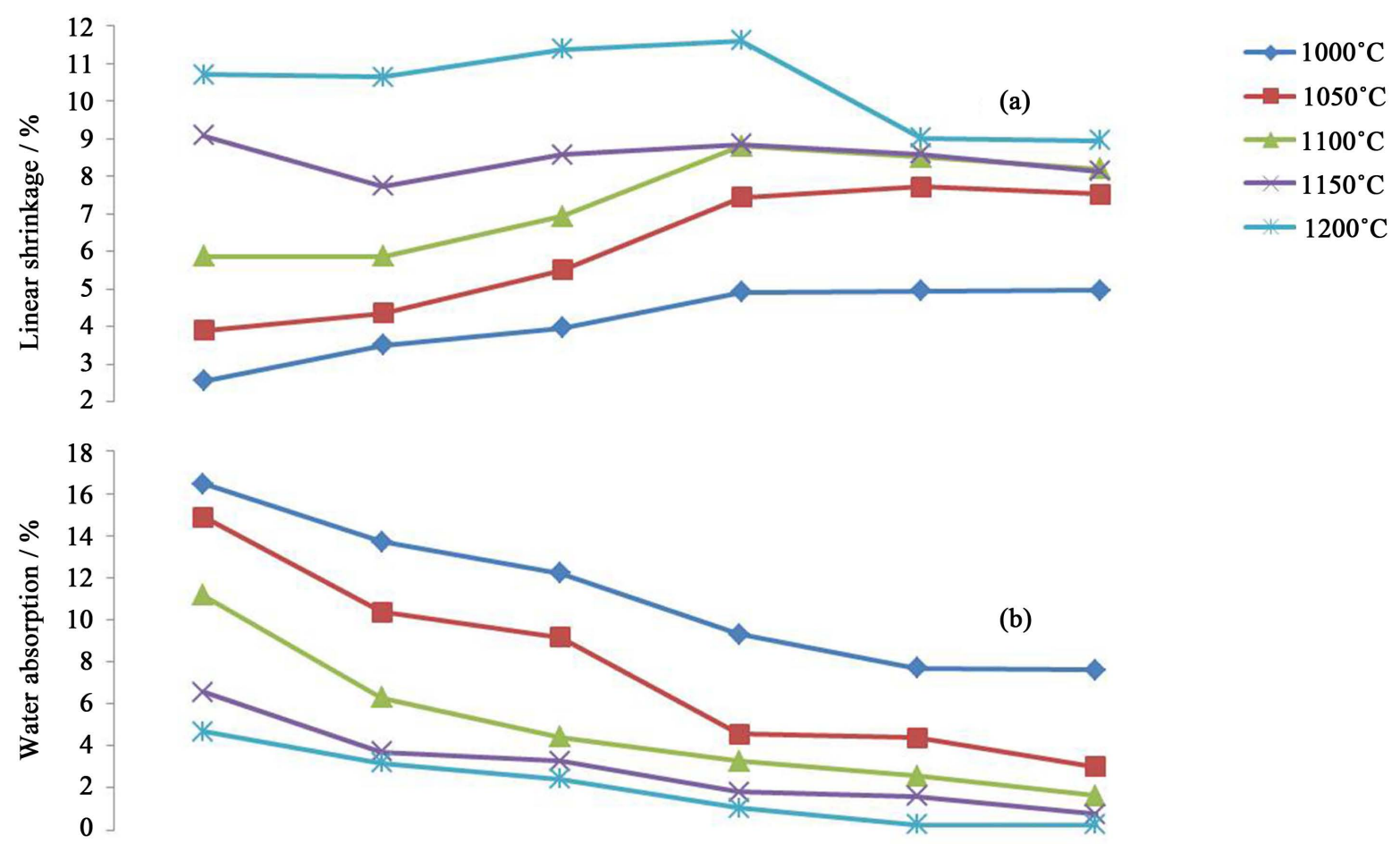

(c)

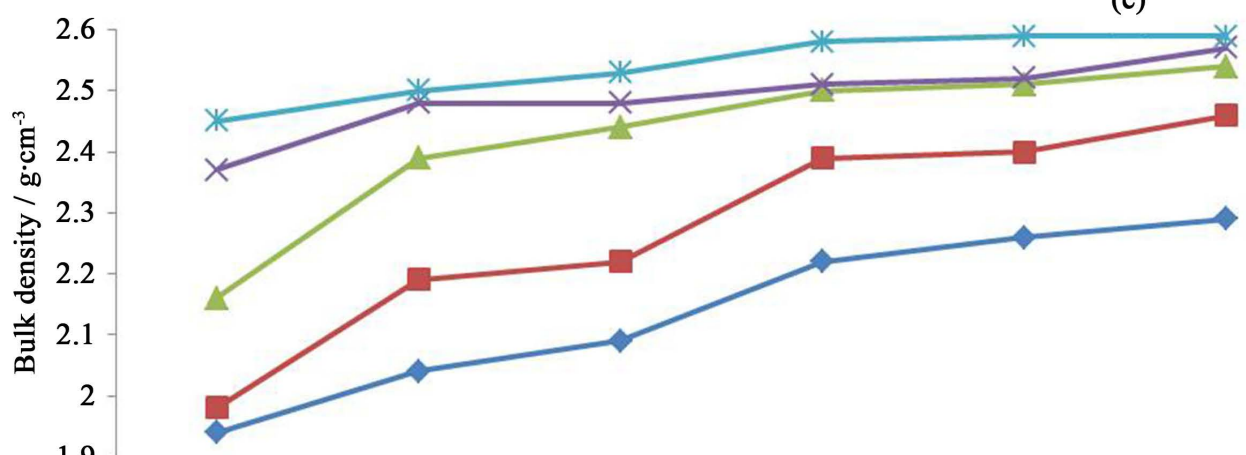

(d)

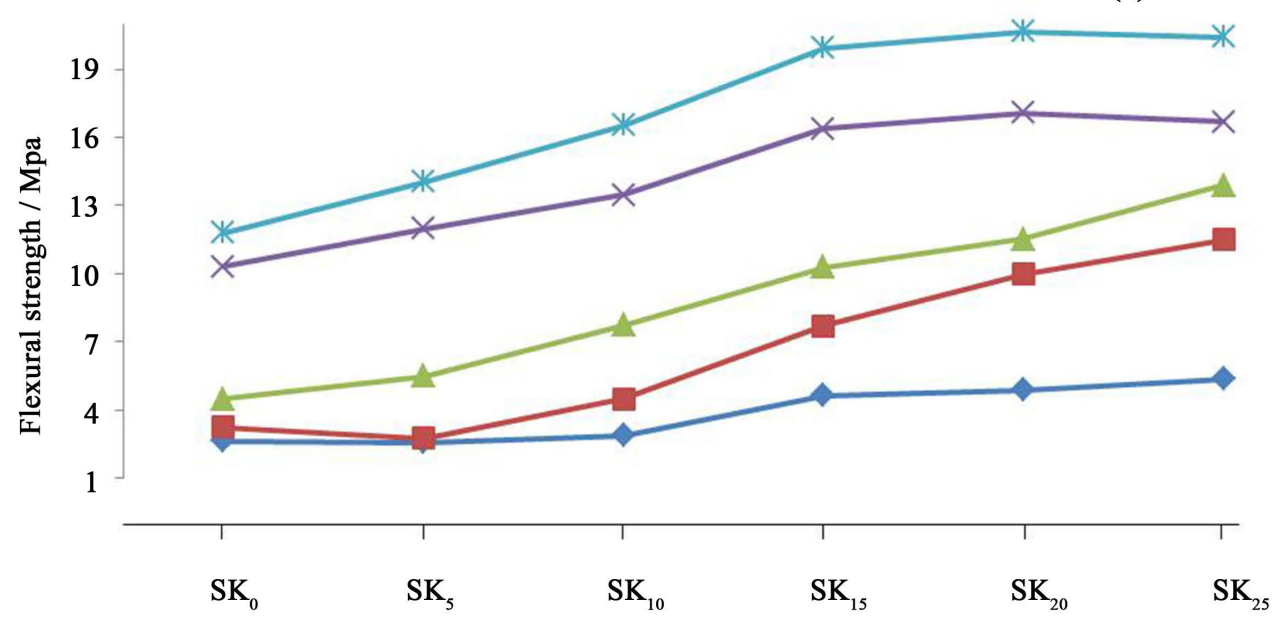

Figure 11. Physical and flexural strength of ceramics of the mixtures $\mathrm{B}_{1}$-SK as a function of amount of additive (SK) and of temperature. ((a): linear shrinkage; (b): water absorption; (c): bulk density; (d): flexural strength). 
within the products of $\mathrm{B}_{1}-\mathrm{B}_{2}$ by the amorphous phase brought about by minerals such as illite (Figure 2) [32]. However the disruption observed in $\mathrm{G}_{40}$ and $\mathrm{G}_{50}$ at $1200^{\circ} \mathrm{C}$ (Figure 9(c)) is a result of bloating within their ceramics via the presence of a high amount of cristobalite (Figure 6(c)). The overall physical characteristics (linear shrinkage, water absorption, bulk density) and increase of amount of mullite and cristobalite within the ceramics of $\mathrm{B}_{1}-\mathrm{B}_{2}$ (Figure 6(b) and Figure 6(c)) are in accordance with the increase of flexural strength (Figure 9(d)). In fact, increasing the sintering and amounts of mullite and cristobalite in aluminosilicate ceramics lead to the increase of mechanical strength [33]. However, it is interesting to mention the positive effect brought about by the mixtures obtained with $20 \% \mathrm{~B}_{2}$ and $80 \% \mathrm{~B}_{1}$ and firing between $1100^{\circ} \mathrm{C}$ and $1150^{\circ} \mathrm{C}$ to get ceramics whose flexural strengths is of class 20 to 35 in the NC-2 Standard of the Cameroonian Norm [34]. Such products are comparable with those obtained with the clays of Bakong which are rich both in iron oxides and alkaline oxides [35]. Nonetheless the values of flexural strength of $B_{1}-B_{2}$ products do not attain $18 \mathrm{MPa}$ because of cracks resulting from the difference in thermal expansion coefficients between amorphous phase (produced by minerals such as illite) and neo-crystalline phases that go through many parts of their microstructures (Figure 8: micrographs $c$ and d). With respect to the ceramics of $B_{1}-S L$ and $B_{1}-S K$, linear shrinkage increases along with temperature and amount of additive (Figure 10(a) and Figure 11(a)) except in the mixtures of $\mathrm{SL}_{5-15}$ and $\mathrm{SK}_{5}$ and $\mathrm{SK}_{20-25}$ respectively at $1100^{\circ} \mathrm{C}, 1150^{\circ} \mathrm{C}$ and $1200^{\circ} \mathrm{C}$. There is a disruption between the value of linear shrinkage of $\mathrm{SL}_{0}$ and $\mathrm{SK}_{0}$ in comparison with those of $\mathrm{SL}_{5-25}$ and $\mathrm{SK}_{5-25}$ which is a result of their mineralogical compositions (Figure 2 and Figure 3). As for the decrease of linear shrinkage in the products of $\mathrm{SK}_{20-25}$ (Figure 11(a)), it is well known that nepheline syenite does not contain quartz, hence firing the preceding samples at 1150 or $1200^{\circ} \mathrm{C}$ leads to the production of an abundant fluid amorphous phase which promotes bloating of the products [36]. The decrease of water absorption (Figure 10(b) and Figure 11(b)) and the increase of bulk density (Figure 10(c) and Figure 11(c)) along with the percentage of additive (SL or SK) and temperature are in agreement with the production of an increasing amount of amorphous phase. On the other hand, the amorphous phase produced by SK (nepheline syenite) is less viscous than that one produced by SL (syenite).Therefore, fluid amorphous phase allows for better diffusion through the network of the materials which leads to more compact products. Hence between $1100^{\circ} \mathrm{C}$ and $1200^{\circ} \mathrm{C}$, the ceramics of $\mathrm{B}_{1}$-SK exhibit lower water absorption values than those of $\mathrm{B}_{1}$-SL (Figure 10(c) and Figure 11(c)). The decrease of bulk density in the products of $\mathrm{SK}_{20-25}$ at $1200^{\circ} \mathrm{C}$ (Figure 11(c)) is in accordance with the presence of a fluid amorphous phase that promotes bloating of the products. Flexural strength as a function of additive (Figure 10(d) and Figure 11(d)) increases along with firing temperature and amount of additive. This is a result of appearance of both mullite and cristobalite (Figure 4 and Figure 5) and the formation of an increasing amount of amorphous phase which promotes good sintering of the products. On the other hand, there is a gap between the values of flexural strength obtained at $1150^{\circ} \mathrm{C}-$ $1200^{\circ} \mathrm{C}$ and those obtained at $1000^{\circ} \mathrm{C}-1100^{\circ} \mathrm{C}$. This is as a result of better sintering of the ceramics produced between $1150^{\circ} \mathrm{C}$ and $1200^{\circ} \mathrm{C}$. In fact, around $1150^{\circ} \mathrm{C}$ much amorphous phase resulting from the melting down of additives (SL and SK) is produced [10] [11]. However, when using the same amount of additive and firing at the same temperature, the ceramics of $B_{1}$-SK exhibit higher flexural strengths than those of $B_{1}$-SL (Figure 10(d) and Figure 11(d)) which is attributed to the fact that the amorphous phase produced by SK is less viscous than that the one produced by SL.

\section{Conclusions}

The thermal behavior and certain characteristics of ceramics produced from mixtures of red clay (rich in iron oxides but poor in fluxing oxides) and additives (ball clay, nepheline syenite and syenite) show that:

In the ceramics of mixtures of red clay-ball clay, the amount of mullite or cristobalite increases along with temperature and amount of additive. Additionally, Young modulus variation indicates that the temperature at which an important densification of the products begins, reduces slightly with the increasing amount of additive. The mixtures made up of $20 \% \mathrm{~B}_{2}$ and $80 \% \mathrm{~B}_{1}$ and fired between $1100^{\circ} \mathrm{C}$ and $1150^{\circ} \mathrm{C}$ give ceramics with flexural strength of class between 20 and 35 in the NC-2 Standard of the Cameroonian Norm.

In the mixtures of red clay-alkaline additive, contrary to mullite, the amount of cristobalite decreases along with the amount of additive and fired temperature. Also, Young modulus variations show that the temperature at which there is an important sintering of the mixtures drops with increasing amount of additive. The ceramics whose mixtures contain up to $15 \%$ alkaline feldspar could be destined to terra cotta when fired between $1050^{\circ} \mathrm{C}$ and $1100^{\circ} \mathrm{C}$. In the mixtures where the amount of alkaline additive goes up to $25 \%$, the products obtained around $1200^{\circ} \mathrm{C}$ can be destined to low water absorption ceramics $(0.70 \%$ to $0.25 \%)$. When using the same 
amount of alkaline additive and firing at the same temperature, the products which result from nepheline syenite are denser than those from syenite. That results from the fact that the amorphous phase produced by nepheline syenite is more wetting than that the one produced by syenite. Ball clay or alkaline feldspars produce an efficient fluxing effect when mixed with kaolinite clay containing great amount of iron oxides and low fluxing oxides.

\section{Acknowledgements}

The authors wish to acknowledge the Director of Ecole Nationale Supérieure de Céramique Industrielle (Limoges, France) for the laboratory facilities and the authorities of the University of Yaoundé I for the financial support of this research work.

\section{References}

[1] Capitâneo, J.L., Da Silva, F.T., Vieira, C.M.F. and Monteiro, S.N. (2005) Reformulation of Kaolinitic Body for Extruded Floor Tiles with Phonolite Addition. Silicates Industriels, 70, 161-165.

[2] Sumer, G.A. (1998) A Search on Pyrometric Cones. Industrial Ceramics, 18, 167-168.

[3] Elimbi, A. (2004) Etude du comportement thermique et des produits de cuisson des argiles kaolinites de Bomkoul. Effets de l'incorporation des adjuvants minéraux locaux. PhD Thesis, University of Yaoundé I, Yaoundé.

[4] Elimbi, A. and Njopwouo, D. (2002) Firing Characteristics of Ceramics from the Bomkoul Kaolinite Clay Deposit (Cameroon). Tile and Brick International, 18, 364-369.

[5] Milheiro, F.A.C., Freire, M.N., Silva, A.G.P. and Holanda, J.N.F. (2005) Densification Behavior of a Red Firing Brasilian Kaolinic Clay. Ceramics International, 31, 757-763. http://dx.doi.org/10.1016/j.ceramint.2004.08.010

[6] Andji, J.Y.Y., Abba, T.A., Jumas, G.J.C., Yvon, J. and Blanchart, P. (2009) Iron Role on Mechanical Properties of Ceramics with Clays from Ivory Coast. Ceramics International, 35, 571-577. http://dx.doi.org/10.1016/j.ceramint.2008.01.007

[7] Jouenne, C.A. (2001) Traité de céramiques et matériaux minéraux. Editions Septima, Paris,.

[8] Ghoneim Sallam, N.E.H. and Ebrahim, D.M. (1990) Role of Accessory Minerals on the Vitrification of Whiteware Compositions. Ceramics International, 16, 19-24. http://dx.doi.org/10.1016/0272-8842(90)90058-N

[9] Acchar, W., Dultra, E.J.V. and Segadaes, A.M. (2013) Untreated Coffee Husk Ashes Used as Flux in Ceramic Tiles. Applied Clay Science, 75-76, 141-147. http://dx.doi.org/10.1016/j.clay.2013.03.009

[10] Kingery, W.D., Bowen, H.K. and Uhlmann, D.R. (1995) Introduction to Ceramics. John Wiley and Sons, New York.

[11] Rogers, W.Z. (2003) Feldspar and Nepheline Syenite. Ceramic Engineering and Science Proceeding, 24, 272-283.

[12] Elimbi, A., Lamilen, D., Chinje, U.M. and Njopwouo, D. (2005) Caractérisation chimico-minéralogique et comportement thermique de trois matériaux feldspathiques camerounais utilisables comme fondants en céramique. Silicates Industriels, 70, 167-173.

[13] Kamseu, E., Bakop, T., Djangang, C., Melo, U.C., Hanuskova, M. and Leonelli, C. (2013) Porcelain Stoneware with Pegmatite and Nepheline Syenite Solid Solutions: Pore Size Distribution and Descriptive Microstructure. Journal of the European Ceramic Society, 33, 2775-2784. http://dx.doi.org/10.1016/j.jeurceramsoc.2013.03.028

[14] Njoya, A., Ekodeck, G.E., Nkoumbou, C., Njopwouo, D. and Tchoua, M.F. (2001) Matériaux argileux au Cameroun: Gisements et exploitation. Proceeding of the 1st Conference on the Valorization of Clay Materials in Cameroon, Yaoundé, 11-12 April 2001, 12-30.

[15] Nibambin, S.S. (2003) Influence des ions fer sur les transformations thermiques de la kaolinite. Ph.D. Thesis, University of Limoges, Limoges.

[16] Traoré, K., Blanchart, P., Jernot, J.P. and Gomina, M. (2007) Caractérisation physicochimique et mécanique de matériaux obtenus à partir d'une argile kaolinite du Burkina Faso. Comptes Rendus de Chimie, 10, 511-517. http://dx.doi.org/10.1016/j.crci.2006.12.009

[17] Pialy, P., Nkoumbou, C., Villiéras, F., Razafitianamaharavo, A., Barres, O., Pelletier, M., Ollivier, G., Bihannic, I., Njopwouo, D., Yvon, J. and Bonnet, J.P. (2008) Characterization for Industrial Applications of Clays from Lembo Deposit, Mount Bana (Cameroon). Clay Minerals, 43, 415-435. http://dx.doi.org/10.1180/claymin.2008.043.3.07

[18] Xiao, Z., Ling, T.C., Poon, C.S., Kou, S.C., Wang, Q. and Huang, R. (2013) Properties Wall Blocks Prepared with High Percentages of Recycled Clay Brick after Exposure to Elevated Temperatures. Construction and Building Materials, 49, 56-61. http://dx.doi.org/10.1016/j.conbuildmat.2013.08.004

[19] Gencel, O., Sutcu, M., Erdogmus, E., Koc, V., Cay, V.V. and Gok, M.S. (2013) Properties of Bricks with Waste Ferrochromium Slag and Zeolite. Journal of Cleaner Production, 59, 111-119. 
http://dx.doi.org/10.1016/j.jclepro.2013.06.055

[20] Sokolar, R., Vodova, L., Grygarova, S., Stubna, I. and Sin, P. (2012) Mechanical Properties of Ceramics Bodies Based on Calcite Waste. Ceramics International.

[21] SNH/UD (2005) Stratigraphie séquentielle et tectonique des dépôts mésozoïques syn-rifts du bassin de Kribi /Campo. Rapport non publié.

[22] Njopwouo, D. (1984) Minéralogie et physico chimie des argiles de Bomkoul et de Balengou (Cameroun). Utilisation dans la polymérisation du styrène et dans le renforcement du caoutchouc naturel. Ph.D. Thesis, University of Yaoundé, Yaoundé.

[23] Regnoult, M. (1986) Synthèse géologique du Cameroun. DMG, Yaoundé.

[24] Lamilen, B.D., Moundi, A., Moupou, M. and Minnyem, D. (1998) Contrôle structural du socle dans la morphologie du massif anorogénique du Koupé (lignes du Cameroun). Geosciences au Cameroun, 1, 191-196.

[25] Huger, M., Fargeot, D. and Gault, C. (2002) High-Temperature Measurement of Ultrasonic Wave-Velocity in Refractory Materials. High Temperatures, High Pressures, 34, 193-201. http://dx.doi.org/10.1068/htwu115

[26] Norme Française NF-P-18-554 (1979) Mesures des masses volumiques, porosité, coefficient d'absorption d'eau et en teneur en eau des gravillons et cailloux. Décembre.

[27] Norme Européenne EN-100 (1982) Détermination de la résistance à la flexion. Octobre 1982.

[28] Brindley, G.W. and Brown, G. (1980) Crystal Structures of Clay Minerals and Their X-Ray Identification. Mineralogical Society, London.

[29] Aliprandi, G. (1966) Matériaux refractaires et céramiques techniques. Edition Septima, Paris.

[30] Suasmoro, S., Smith, D.S., Lejeune, M., Huger, M. and Gault, C. (1992) High Temperature Ultrasonic Characterization of Intrinsic and Microstructural Change in Ceramic $\mathrm{YBa}_{2} \mathrm{CU}_{3} \mathrm{O}_{7-\delta}$. Journal of Materials Research, 7, 1629-1635. http://dx.doi.org/10.1557/JMR.1992.1629

[31] Castelein, O. (2000) Influence de la vitesse du traitement thermique sur le comportement d'un kaolin: Application au frittage rapide. Ph.D. Thesis, Université de Limoges, Limoges.

[32] Chakraborty, A.K. (1992) Supplementary Alkali Extraction Studies of $980^{\circ} \mathrm{C}$ Heated Kaolinite by X-Ray Diffraction Analysis. Journal of Materials Science, 27, 2075-2082. http://dx.doi.org/10.1007/BF01117920

[33] Kristofferson, A., Ekberg, J., Leandersson, H. and Carlson, R. (1993) High-Strength Triaxial Porcelainized Stoneware. International Ceramics Journal, 10, 99-103.

[34] Normes Camerounaises NC-2 (2010) Norme de description. Brique de terre cuite: Désignation et classification.

[35] Elimbi, A., Founyapté, S. and Njopwouo, D. (2004) Effets de la température de cuisson sur la composition minéralogique et les propriétés physiques et mécaniques de deux matériaux du gisement argileux de Bakong (Cameroun). Annales de Chimie, Science des Matériaux, 29, 67-77. http://dx.doi.org/10.3166/acsm.29.2.67-77

[36] Salem, A., Jazayeri, S.H., Rastelli, E. and Timellini, G. (2009) Dilatometric Study of Shrinkage during Process for Porcelain Stoneware Body in Presence of Nepheline Syenite. Journal of Materials Processing Technology, 29, 124-126. 
Scientific Research Publishing (SCIRP) is one of the largest Open Access journal publishers. It is currently publishing more than 200 open access, online, peer-reviewed journals covering a wide range of academic disciplines. SCIRP serves the worldwide academic communities and contributes to the progress and application of science with its publication.

Other selected journals from SCIRP are listed as below. Submit your manuscript to us via either submit@scirp.org or Online Submission Portal.
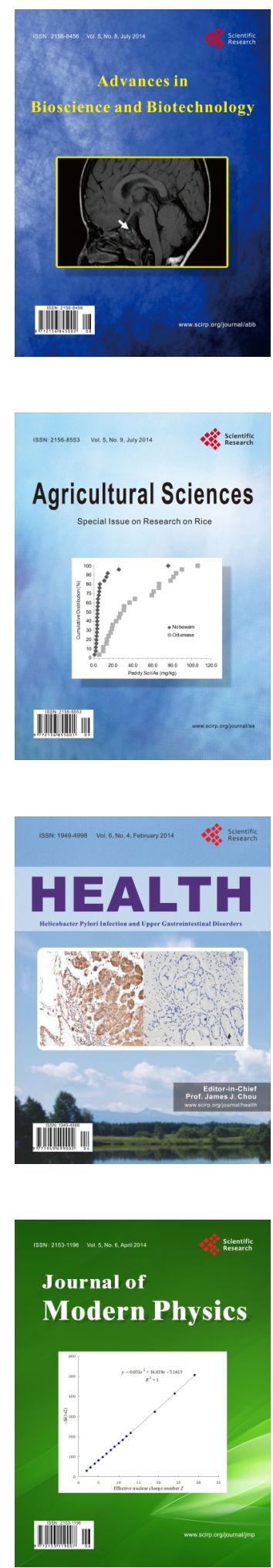
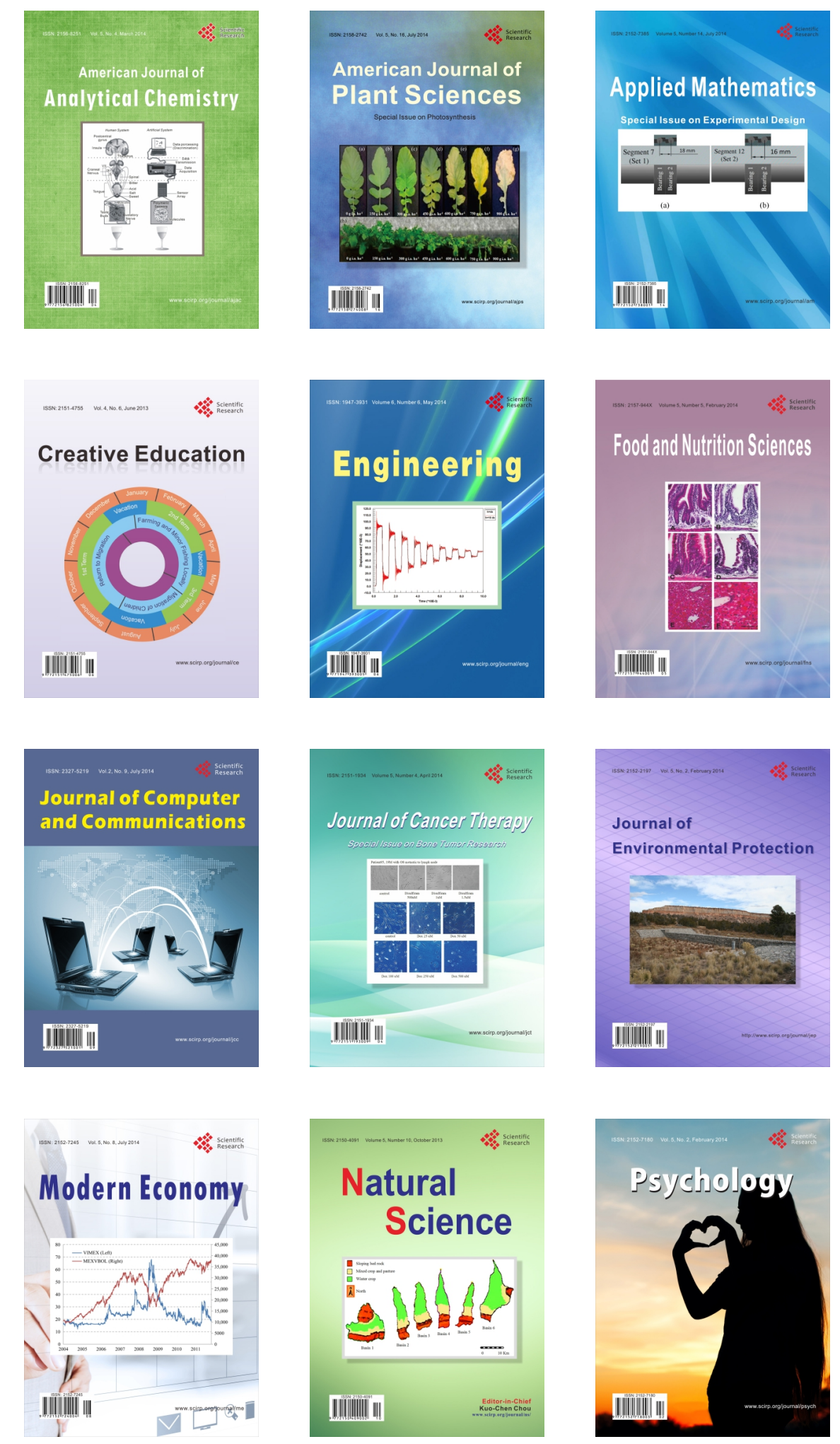